\title{
Characteristics and Evolution of Nitrogen in the Heavy Components of Algae Pyrolysis Bio-Oil
}

\author{
Jun Li, ${ }^{\perp}$ Zhe Xiong, ${ }^{\perp}$ Kuo Zeng, ${ }^{*}$ Dian Zhong, Xin Zhang, Wei Chen, Ange Nzihou, Gilles Flamant, \\ Haiping Yang, and Hanping Chen
}

\begin{abstract}
Algae pyrolytic bio-oil contains a large quantity of Ncontaining components (NCCs), which can be processed as valuable chemicals, while the harmful gases can also be released during bio-oil upgrading. However, the characteristics of NCCs in the bio-oil, especially the composition of heavy NCCs (molecular weight $\geq 200 \mathrm{Da}$ ), have not been fully studied due to the limitation of advanced analytical methods. In this study, three kinds of algae rich in lipids, proteins, and carbohydrates were rapidly pyrolyzed $\left(10-25^{\circ} \mathrm{C} / \mathrm{s}\right)$ at different temperatures $\left(300-700{ }^{\circ} \mathrm{C}\right)$. The biooil was analyzed using a Fourier transform ion cyclotron resonance mass spectrometer equipped with electrospray ionization, and the characteristics and evolution of nitrogen in heavy components

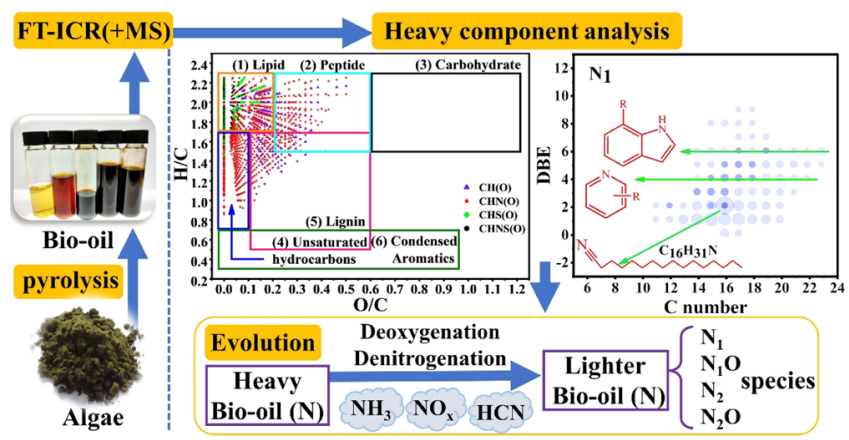
were first obtained. The results indicated that the molecular weight of most heavy NCCs was distributed in the 200-400 Da range. $\mathrm{N}_{1-3}$ compounds account for over $60 \%$ in lipid and protein-rich samples, while $\mathrm{N}_{0}$ and $\mathrm{N}_{4}$ components are prominent in carbohydrate-rich samples. As temperature increases, most NCCs become more aromatic and contain less $\mathrm{O}$ due to the strong Maillard and deoxygenation reactions. Moreover, the heavier NCCs were promoted to form lighter compounds with more nitrogen atoms through decomposition (mainly denitrogenation and deoxygenation). Finally, some strategies to deal with the NCCs for highquality bio-oil production were proposed.
\end{abstract}

\section{INTRODUCTION}

Algae show great potential as a thermochemical feedstock due to their high photosynthetic efficiency, the simple nutrient demand, and no need for an arable land. ${ }^{1,2}$ Pyrolysis is considered to be a promising method for the efficient beneficiation of algae as pyrolysis not only avoids the operating costs of high pressure required by hydrothermal liquefication but also results in high bio-oil yields (up to $80 \mathrm{wt} \%$ ) and in a large share of feedstock energy (up to 70\%) in bio-oil., However, the bio-oil produced from pyrolysis of algae has some drawbacks, such as a high nitrogen content and plenty of heavy components (defined as the compounds with a molecular weight $>200 \mathrm{Da}$ in this study). ${ }^{5,6}$ These properties limit the application of algae bio-oil.

The N-containing components (NCCs) in bio-oil can be processed as valuable chemicals in numerous fields. For example, nitriles are widely used in pharmaceuticals and agrochemicals, and alkylamines can be used as industrial solvents. ${ }^{7}$ However, NCCs in bio-oil will also lead to the release of large amounts of harmful gases such as $\mathrm{NO}_{x}, \mathrm{NH}_{3}$, and $\mathrm{HCN}$ during pyrolysis or subsequent combustion and upgrading processes. ${ }^{8}$ Therefore, characterizing the composition of NCCs in algae pyrolytic bio-oil is necessary not only for nitrogen removal but also for efficient utilization of the products (such as choosing appropriate upgrading methods).

The heavy components in bio-oil are characterized by poor volatility, a high molecular mass, and high viscosity due to the complex structure. ${ }^{9,10}$ The pyrolysis residence time becomes longer under high viscosity, causing the heavy components to be converted into undesirable products (e.g., heavy tar) via polymerization. ${ }^{11}$ Besides, the heavy components contain multiple functional groups, making them rather reactive. ${ }^{12}$ Studies have reported that the heavy components can easily form coke in thermal treatment, which can lead to the blockage of the reactor and catalyst deactivation. ${ }^{9-11}$ The lack of information on the molecular structure of heavy components makes it difficult to develop catalysts/processes for their effective conversion and eventually creates challenges for biooil upgrading. 
Great efforts have been devoted to investigating the composition of NCCs in algae pyrolysis bio-oil. Gas chromatography-mass spectrometry $(\mathrm{GC}-\mathrm{MS})$ or $\mathrm{GC} \times$ GC-MS analysis leads to obtaining some chemical dates of hundreds of volatile and semi-volatile compounds. Nevertheless, information is limited about less volatile and largemolecular-weight compounds. ${ }^{11,12}$ Previous studies have shown that there was a considerable number of long-chain amines, long-chain nitriles, and nitrogen-containing heterocycles with a large molecular weight in algae pyrolysis bio-oil. ${ }^{13}$ Fourier transform infrared (FTIR) spectroscopy or nuclear magnetic resonance methods may result in more useful information on the bulk properties of the large molecular compounds, but these methods are not able to distinguish individual components. ${ }^{14,15}$ As a result, the composition of NCCs with less volatile compounds and a high molecular weight are still unclear. Therefore, it is necessary to obtain detailed information on the NCCs in heavy components.

Fourier transform-ion cyclotron resonance-mass spectrometry (FT-ICR-MS) equipped with electrospray ionization (ESI) has been successfully applied in molecular characterization of heavy components in bio-oils. ${ }^{16,17}$ It has an ultrahigh resolving power (>200,000), which can assign a unique element composition to each mass spectrum peak. ${ }^{18}$ Among them, nitrogen-, phosphorus-, and sulfur-containing compounds were detected in addition to major oxygen- and carbon-containing compounds. Obviously, it can be speculated that ESI FT-ICRMS can be useful for the detection of algae pyrolytic bio-oil and can provide more molecular-level information of the NNCs in the heavy components at the molecular level.

The effects of algae pyrolysis parameters on bio-oil have been extensively studied. Pourkarimi and Zhong et al. ${ }^{19,20}$ concluded that the pyrolysis bio-oil yield of algae reached the maximum at $400-550{ }^{\circ} \mathrm{C}$. Gong et al. ${ }^{21}$ investigated the pyrolysis characteristics of Chlorella and Dunaliella salina. The nitrogen content in bio-oil ranged from 6-10 wt \% and gradually increased as the temperature increased. In Addition, Leng et al. ${ }^{6}$ found that the biochemical composition of algae also affected the properties of bio-oil. Carbohydrates can promote nitrogen enrichment, while proteins and lipids were conducive to nitrogen removal. $\mathrm{Du}$ and Aysu et al. ${ }^{22,23}$ obtained the pyrolysis pathways of main algae compounds such as carbohydrates, proteins, and lipids by model compound pyrolysis. However, studies have shown that these compounds have interactions in the pyrolysis process. ${ }^{13,24}$ Niu et al. ${ }^{11}$ found that lipids can interfere with the protein decomposition, and carbohydrates facilitated the formation of $\mathrm{N}$-heterocyclic compounds. Obviously, there is a difference in the pyrolysis mechanism between the algae and the model compounds. Consequently, it is reasonable to choose algae rich in different components to explore the effects of component differences on pyrolysis, which also matches the industrial practical application. $^{11,13}$

Three species of algae rich in different components (lipids, proteins, and carbohydrates) were selected to conduct rapid pyrolysis at five different temperatures $(300,400,500,600$, and $700{ }^{\circ} \mathrm{C}$ ) in a fixed-bed reactor system. ESI FT-ICR-MS in the positive mode was used to analyze the algae pyrolytic bio-oils, and GC-MS was performed to confirm the structural motifs of nitrogen species in parallel. The information at the molecular level of NCCs in the heavy compounds under different parameters was first obtained, and the evolution routes of nitrogen in heavy bio-oil compounds were proposed on this basis. This information may help to provide constructive guidance for bio-oil upgrading and utilization by processing the NCCs and heavy components.

\section{MATERIALS AND METHODS}

2.1. Materials. The lipid-rich Nannochloropsis sp. (NS) was purchased from Yantai Hairong Biology Technology Co., Ltd., and the protein-rich Spirulina platensis (SP) and the carbohydrate-rich Enteromorpha prolifera (EP) were purchased from Qingdao Haixingyuan Biology Technology Co., Ltd. These algae were dried at $105{ }^{\circ} \mathrm{C}$ for $20 \mathrm{~h}$ and then pulverized and sieved to $<30 \mu \mathrm{m}$ before pyrolysis. Proximate analysis was conducted based on GB/T 28731-2012, and ultimate analysis was conducted using a CHNS/O analyzer (Vario Micro cube, Germany). In addition, the protein content and lipid content were obtained according to the Kjeldahl method (GB 5009.5-2000) and the Sohlet method (GB 5009.6-2003), respectively. ${ }^{17}$ All these results are listed in Table 1.

Table 1. Properties of the Different Algae

\begin{tabular}{|c|c|c|c|}
\hline samples & SP & NS & $\mathrm{EP}$ \\
\hline \multicolumn{4}{|c|}{ Proximate Analysis (wt \%), Air Dry Basis } \\
\hline moisture & 7.56 & 5.24 & 7.20 \\
\hline volatiles & 80.94 & 78.13 & 61.01 \\
\hline Ash & 5.76 & 5.16 & 27.02 \\
\hline fixed carbon & 5.74 & 11.47 & 4.77 \\
\hline \multicolumn{4}{|c|}{ Ultimate Analysis (wt \%), Air Dry Basis } \\
\hline $\mathrm{C}$ & 46.05 & 43.36 & 28.44 \\
\hline $\mathrm{H}$ & 6.41 & 6.09 & 4.42 \\
\hline $\mathrm{N}$ & 10.44 & 7.27 & 1.38 \\
\hline$S$ & 0.58 & 0.70 & 2.79 \\
\hline $\mathrm{O}^{a}$ & 26.12 & 29.26 & 28.75 \\
\hline \multicolumn{4}{|c|}{ Biochemical Compositions (wt \%), Air Dry Basis } \\
\hline lipids & 10.23 & 37.81 & 2.17 \\
\hline proteins & 64.21 & 43.62 & 7.85 \\
\hline carbohydrates $^{a}$ & 12.24 & 8.17 & 55.76 \\
\hline
\end{tabular}

2.2. Experimental Methods. Rapid pyrolysis of algae samples was carried out in a fixed-bed reactor system (Figure S2), which mainly comprises a quartz basket, a quartz reactor (610 mm length, $45 \mathrm{~mm}$ i.d.), a quartz tube (15 $\mathrm{mm}$ i.d.), a condensing unit (ice-water bath), and a gas collection unit. Before each trial, $1 \mathrm{~g}$ of the algae sample was loaded in the quartz basket and fixed on the top of the reactor together. Then, $500 \mathrm{~mL} / \mathrm{min} \mathrm{N}_{2}$ (purity > 99.9\%) flow was introduced to purge the reactor for an oxygen-free condition. When the reactor reached the target temperatures $\left(300-700{ }^{\circ} \mathrm{C}\right.$ ), the $\mathrm{N}_{2}$ flow rate was adjusted to $200 \mathrm{~mL} / \mathrm{min}$; then, the quartz basket was quickly lowered to the center of the reactor, and the algae pyrolysis started. Each experiment was performed for $20 \mathrm{~min}$ to ensure the complete release and collection of volatiles. The bio-oil was collected by methanol and stored in the freezer $\left(-16{ }^{\circ} \mathrm{C}\right)$ before GC-MS and FT-ICR-MS analysis. The biooil yield was measured by the mass difference of the quartz tubes and the condensing unit.

2.3. Characterization of Bio-Oil. The ESI-FT-ICR-MS analyses were conducted with a $7.0 \mathrm{~T}$ Solarix (Bruker, Germany) in the positive-ion mode. Previous literature studies reported that ESI was an effective approach to ionize polar 


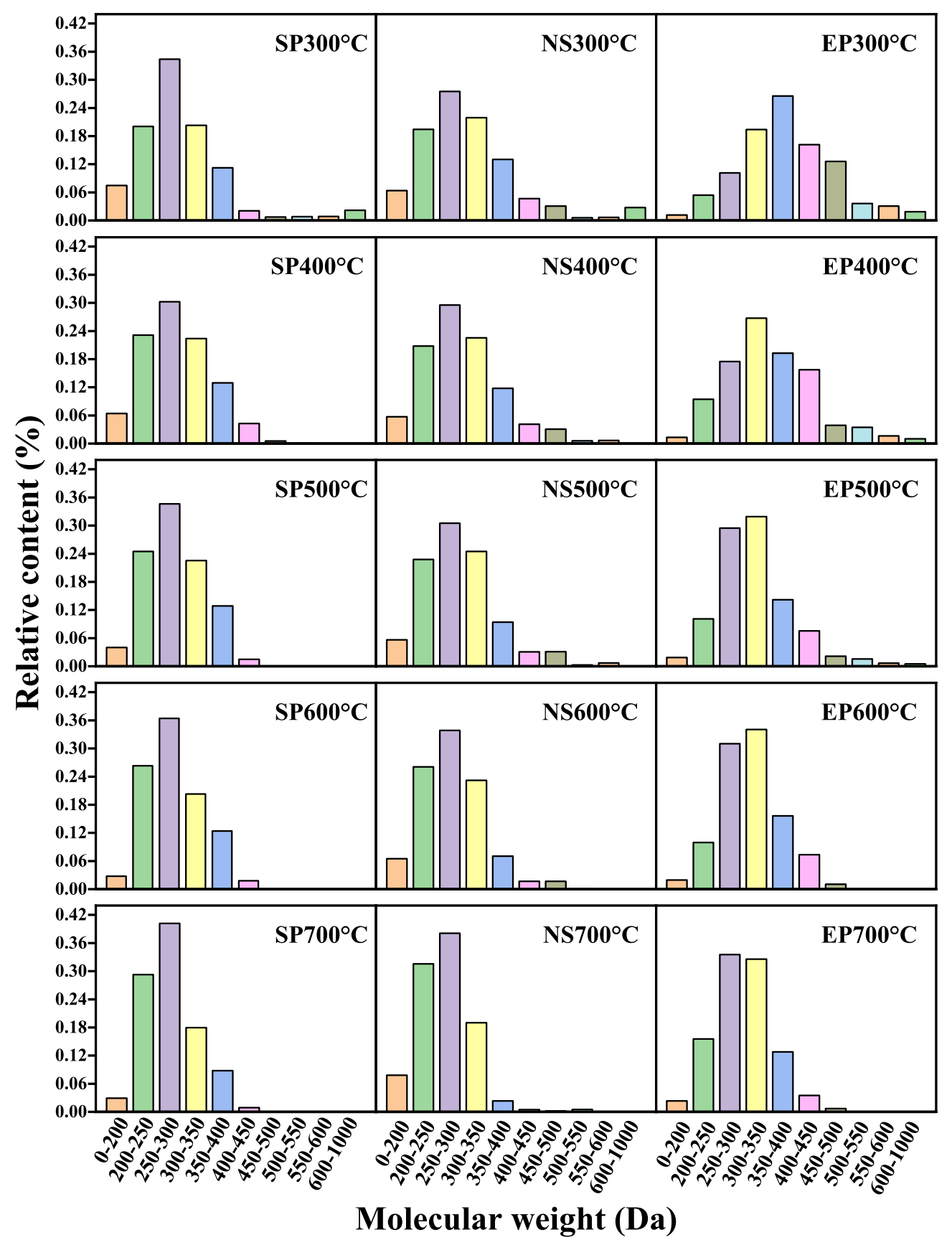

Figure 1. Mass distribution of bio-oil compounds under the investigated temperatures.

compounds ( $\mathrm{N}, \mathrm{O}$, and $\mathrm{S}$ heteroatoms) for MS analysis and that the ESI positive ionization mode favored the analysis of nitrogenous compounds. ${ }^{25,26}$ In this study, the mass spectra of $\mathrm{NS}$ in both the positive- and negative-ion modes at $500{ }^{\circ} \mathrm{C}$ (Figure S1) can also support this claim. The emitter voltage, capillary voltage, and end plate offset were set as 4.0, 4.5, and $-0.5 \mathrm{kV}$, respectively. An argon-filled collision pool was operated at $1.4 \mathrm{MHz}$ and $1200 \mathrm{Vpp}$ of radio-frequency amplitude. Ions were accumulated in the pool for $0.01 \mathrm{~s}$ prior to being transferred to the ICR cell for detection, and the time of flight was set as $0.5 \mathrm{~ms}$. Besides, a total of 128 scans were coadded to enhance the signal-to-noise ratio $(\mathrm{S} / \mathrm{N})$. Under these conditions, a resolving power of $1,000,000$ full width at halfmaximum at $400 \mathrm{~m} / z$ and the mass accuracy $<1$ ppm were achieved. The final mass spectrum of each sample was obtained in the range of $100-1000 \mathrm{~m} / z$, and the data size of each sample was 240 Mbyte.

The bio-oil samples were further diluted with LC-MS-grade methanol (Merck) to $0.35 \mathrm{mg} / \mathrm{mL}$ and directly infused into the ion source at a flow rate of $120 \mu \mathrm{L} / \mathrm{h}$. Before analysis, the bio-oil solution was spiked with 0.5 vol \% of formic acid (Merck) as an ESI modifier to enhance the ionization of the basic compounds, ${ }^{27,28}$ and sodium formate was used to calibrate the instrument. ${ }^{18}$ In addition, the solvent (methanol) was also analyzed, and the most prominent peaks in the solvent mass spectra were removed from consideration in the sample results. Data with $\mathrm{S} / \mathrm{N}>5$ were selected for analysis by a MATLAB script, ${ }^{29,30}$ and Microsoft Excel and Origin 8.9 software were used for data sorting and visualization. 
The volatile compounds in the bio-oil solutions were identified using GC-MS (Agilent 7890 A series GC coupled with a 5975 MS detector) with a capillary column (HP-5MS, $30 \mathrm{~m} \times 0.25 \mathrm{~mm}$ i.d. $\times 0.25 \mu \mathrm{m}$ d.f.). More detailed information of the instrument has been reported in our previous work. ${ }^{31}$ Finally, all the compounds were identified using a National Institute of Standards and Technology library (NIST 2011).

2.4. Molecular Formula Calculation. A MATLAB script was used to calculate the molecular formula of the selected data. First, the limitation of the molecular formula (based on the standards of the National High Magnetic Field Laboratory in Tallahassee, $\mathrm{FL}^{32}$ ) was $\leq 50{ }^{12} \mathrm{C}, 2{ }^{13} \mathrm{C}, 100{ }^{1} \mathrm{H}, 30{ }^{16} \mathrm{O}, 5$ ${ }^{14} \mathrm{~N}, 2{ }^{32} \mathrm{~S}, 1^{33} \mathrm{~S}$, and $1^{31} \mathrm{P}$. The masses of common elements and the corresponding isotopes used in the script are listed in Table S1. Besides, the following constraints were applied to the atomic composition: (1) $\mathrm{O} / \mathrm{C} \leq 1.2$; (2) $0.35 \leq \mathrm{H} / \mathrm{C} \leq 2.25$; (3) $\mathrm{N} / \mathrm{C} \leq 0.5$; (4) $\mathrm{S} / \mathrm{C} \leq 0.2$; (5) N, S $<$ O. Second, the relative and absolute mass errors of molecular formula assignments were $<1 \mathrm{ppm}$ and $<0.001$, respectively. Additionally, the double-bond equivalent (DBE), an index representing the unsaturation of molecules, can be calculated by eq 1 , and it must be a non-negative integer value. ${ }^{33}$ Finally, all molecular formulas need to satisfy the N-rules ${ }^{26}$

$$
\mathrm{DBE}=1+0.5 \times(2 \mathrm{C}-\mathrm{H}+\mathrm{N}+\mathrm{P})
$$

where $\mathrm{C}, \mathrm{H}, \mathrm{N}$, and $\mathrm{P}$ represent the atom number.

For macromolecules $(m / z \geq 500)$, which may have multiple potential formula assignments. The compound identification algorithm (CIA) was used to solve this issue according to the description proposed in the previous literature. ${ }^{34}$ Briefly, the bio-oil compounds detected by FT-ICR-MS were assumed to be singly charged, and the detected mass in the positive-ion mode can add an $\mathrm{H}$-atom and subtract an electron to generate a neutral mass. ${ }^{34}$ On this basis, each functional group relationship was converted into a mass difference (e.g., $\left.\Delta \mathrm{CH}_{2}=14.01565008 \mathrm{Da}, \Delta \mathrm{NH}_{2}=16.01872408 \mathrm{Da}\right)$. Therefore, if one of the potential formulae for a higher mass peak shared a fixed difference value with the lower mass peak assigned by a unique formula, then this potential formula is the correct assignment for the higher peak. For example, the molecular mass of $\mathrm{C}_{16} \mathrm{H}_{41} \mathrm{O}_{5} \mathrm{~N}$ is $399.29792233 \mathrm{Da}$, and if there is a macromolecule of $609.53267353 \mathrm{Da}$, then its corresponding molecular formula is identified as $\mathrm{C}_{31} \mathrm{H}_{71} \mathrm{O}_{5} \mathrm{~N}$ because the mass difference between these two molecules is 15 times of the $\mathrm{CH}_{2}$ group. Moreover, the MATLAB script parses the pre-assigned formulae into two arrays, those with unique formula assignments and those with more than one formula assignments. For the latter array, the hierarchy to determine the final molecular formula was followed by (1) CIA analysis, (2) the least number of $S+N+P$, and the (3) lowest relative mass error.

\section{RESULTS AND DISCUSSION}

3.1. Bio-Oil Yield. The bio-oil yields of the three samples are shown in Figure S3. As temperature increases, all samples exhibit a similar trend. The maximum bio-oil yields are obtained at $500{ }^{\circ} \mathrm{C}$, with $55.5,53.5$, and 33.0 wt \% for SP, NS, and EP, respectively. This trend is similar to the results reported in the previous literature. ${ }^{20,35}$ EP generates less bio-oil than the other two samples and is less sensitive to temperature when the temperature is higher than $400{ }^{\circ} \mathrm{C}$, probably because SP and NS have a higher volatile content, while EP has a higher inorganic ash content. ${ }^{36}$ Besides, a rapid heating rate can avoid the re-polymerization of the algae lipid vapor, improving the bio-oil yield of high-lipid algae. ${ }^{37}$ On the other hand, Wang et al. ${ }^{38}$ found that the main weight loss peak of carbohydrates appeared before $300{ }^{\circ} \mathrm{C}$, while those of lipids and proteins appeared after $300{ }^{\circ} \mathrm{C}$. This leads to a higher biooil yield of carbohydrate-rich EP at $300{ }^{\circ} \mathrm{C}$.

3.2. Evolution of Mass Distribution and Elementary Composition. Figure 1 illustrates the mass distribution of the bio-oil compounds analyzed by FT-ICR-MS and the MATLAB script at different temperatures. Many heavy components (>200 Da) in the bio-oils are detected, and the molecular weight of all compounds presents a normal distribution and mainly distributes in the range of 0-500 Da. Besides, EP always shows more heavy components in the range of molecular weights $>400 \mathrm{Da}$ compared with SP and NS at 300-700 ${ }^{\circ} \mathrm{C}$. Therefore, the possible effects of heavy components in bio-oil should be carefully considered during the pyrolysis, especially for the carbohydrate-rich feedstock. With the increase of temperature, the mass distribution of all bio-oil samples presents the characteristic of a transition to the lighter-component range. At $700{ }^{\circ} \mathrm{C}$, most bio-oil components concentrate in the range of 200-350 Da, which can account for up to $90 \%$ of the total content. This result suggests that the decomposition of the components with a large molecular weight is enhanced at higher temperatures. It is consistent with the results obtained by $\mathrm{Hu}$ et al. ${ }^{39}$

Table 2 lists the detailed element composition information of the heavy components ( $>200 \mathrm{Da})$ to analyze the bulk

Table 2. Chemical Characteristics of the Heavy Components in Bio-Oil ${ }^{a}$

$\begin{array}{ccccccc}\text { samples } & T\left({ }^{\circ} \mathrm{C}\right) & \mathrm{AMW} & \mathrm{ADBE} & \mathrm{AO} / \mathrm{C} & \mathrm{AH} / \mathrm{C} & \mathrm{ANN} \\ \mathrm{SP} & 300 & 319.84 & 4.36 & 0.107 & 1.713 & 1.828 \\ & 400 & 291.94 & 4.46 & 0.083 & 1.702 & 1.838 \\ & 500 & 285.03 & 5.52 & 0.068 & 1.594 & 2.069 \\ & 600 & 280.60 & 6.50 & 0.058 & 1.490 & 2.265 \\ \mathrm{NS} & 700 & 277.68 & 8.54 & 0.041 & 1.270 & 2.661 \\ & 300 & 311.70 & 5.36 & 0.081 & 1.630 & 2.015 \\ & 400 & 307.48 & 5.57 & 0.094 & 1.613 & 2.079 \\ & 500 & 294.81 & 5.65 & 0.107 & 1.589 & 2.136 \\ \mathrm{EP} & 600 & 288.77 & 6.60 & 0.070 & 1.492 & 2.144 \\ & 700 & 272.88 & 8.10 & 0.066 & 1.317 & 2.509 \\ & 300 & 383.30 & 6.52 & 0.257 & 1.580 & 1.886 \\ & 400 & 357.95 & 6.66 & 0.204 & 1.492 & 1.842 \\ & 500 & 327.40 & 5.83 & 0.151 & 1.557 & 1.719 \\ & 600 & 324.18 & 5.80 & 0.148 & 1.562 & 1.713 \\ & 700 & 313.31 & 5.47 & 0.127 & 1.661 & 2.071\end{array}$

${ }^{a_{\mathrm{T}}}$, temperature. A, average. $\mathrm{NN}, \mathrm{N}$ number.

physicochemical properties. The parameters are defined and calculated by the formula according to the reported literatures ${ }^{40,41}$

$$
\mathrm{AMW}=\sum_{n}\left(\mathrm{MW}_{n} \times I_{n}\right) /\left(\sum_{n} I_{n}\right)
$$

where AMW is the average molecular weight, $I$ denotes the peak intensity, and $n$ is the molecular number. The MW position can be replaced with $\mathrm{DBE}, \mathrm{O} / \mathrm{C}, \mathrm{H} / \mathrm{C}$, and $\mathrm{N}$ number. 
Obviously, as temperature increases, for the bio-oil generated from SP and NS, the AMW, $\mathrm{AO} / \mathrm{C}$, and $\mathrm{AH} / \mathrm{C}$ gradually decrease, while the $\mathrm{DBE}$ and $\mathrm{ANN}$ gradually increase. The heavy compounds become lighter but more condensed, and the heating process may be accompanied by a stronger condensation related to carbon double bonds as well as amino groups and carboxyl groups. ${ }^{42}$ Besides, the cracking of $\mathrm{N}$-containing heterocyclic compounds in bio-char can increase the ANN in bio-oil. ${ }^{43}$ For EP, it shows different trends in $\mathrm{ADBE}$ and $\mathrm{AH} / \mathrm{C}$, both of which change slightly. It appears that the carbohydrates in bio-oil have some effects on maintaining the stability of the heavy components in bio-oil. Interestingly, the ANN of SP and NS is not significantly different from that of EP despite the low nitrogen content of EP. It is essential to study the heavy bio-oil components from different feedstocks since the bulk physicochemical properties of the heavy compounds are diverse. In addition, the ANN of bio-oils sharply increases (about 17.5-20.9\%) from 600 to 700 ${ }^{\circ} \mathrm{C}$, and special attention should be paid to downstream production and processing to prevent pollution and reduce catalyst poisoning caused by the NCCs. ${ }^{44}$

The total nitrogen abundance in heavy components of biooil is obtained by eq 3 , and it can be used for the semiquantitative analysis on the nitrogen abundance in different feedstocks

$$
\mathrm{TA}=\sum_{k}\left(X \times I_{k}\right) \times Y
$$

where TA is the total abundance, $k$ is the number of NCCs, $X$ is the NN in NCCs, and $Y$ is the bio-oil yield.

It is easy to derive that different feedstocks show significantly different trends in total $\mathrm{N}$ abundance, as shown in Figure 2. Under the investigated temperatures, SP sharply

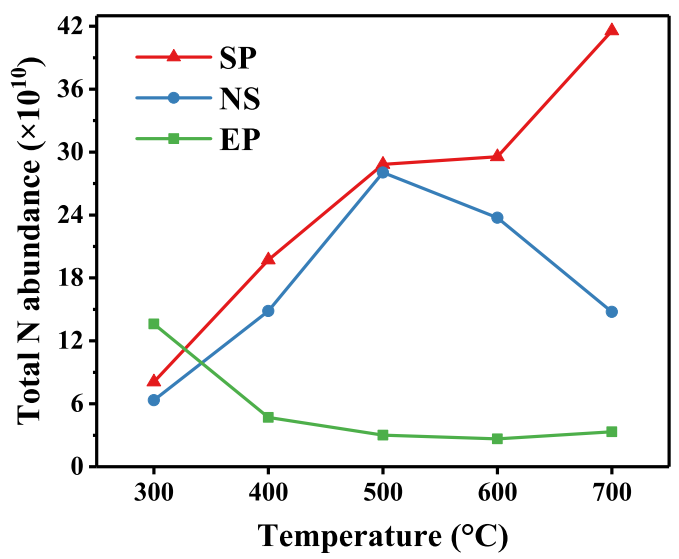

Figure 2. Total $\mathrm{N}$ abundance under the investigated temperatures (based on EP).

increases, NS first increases and then decreases, reaching the peak at $500{ }^{\circ} \mathrm{C}$, while EP decreases before $400{ }^{\circ} \mathrm{C}$ and remains relatively stable after $400{ }^{\circ} \mathrm{C}$. This is inconsistent with the results of bio-oil measured using the $\mathrm{CHNS} / \mathrm{O}$ analyzer in a previous study, ${ }^{43}$ which reported that nitrogen contents in pyrolytic bio-oils from three algae all present a maximum with temperature. This actually shows the uniqueness of heavy components in bio-oil, and thus, an in-depth study is required.

Although the optimal temperature for a high bio-oil yield from all feedstocks is $500{ }^{\circ} \mathrm{C}$, the total nitrogen abundance in SP and NS heavy components is also high at this temperature, which directly affects the bio-oil quality and increases the harmfulness of bio-oil. Therefore, in the pyrolysis process of the nitrogen-rich feedstock, a high bio-oil yield should not be blindly pursued, but the bio-oil composition such as heavy components and NCCs should also be considered.

3.3. Evolution of NCCs. The ANN and total nitrogen abundance reflect the overall concentration of nitrogen in the heavy components of bio-oil, but it does not help to clarify the distribution and composition of the heavy NCCs derived from different feedstocks. The relative content of heavy components with different NNs is calculated by eq 4 , and the results are shown in Figure 3.

$$
\mathrm{RC}_{X}=\sum_{m} I_{(X) m} / \sum_{n} I_{n}
$$

where $\mathrm{RC}_{X}$ represents the relative content of the compounds containing $X \mathrm{NN}$ and $m$ represents its number.

Clearly, for SP and NS, $\mathrm{N}_{2}$ components dominate; this is consistent with the results of NCCs obtained in other literature studies. ${ }^{39,45} \mathrm{~N}_{1-3}$ components account for about $60-75 \%$, which should be the pyrroles, pyridines, butyronitriles, and heterocyclic amines in the positive-ion mode. ${ }^{40,46}$ For EP, the NCCs are relatively less, which may due to the low nitrogen content in the feedstock. $\mathrm{N}_{4}$ components are more abundant in NCCs, and they are probably mainly heterocyclic amines, such as 2-amino-6-methyldipyrido-[1,2- $\alpha: 3^{\prime}, 2^{\prime}$-d $]$ imidazole and 2aminodipyrido-[1,2- $\alpha: 3^{\prime}, 2^{\prime}$-d] imidazole. ${ }^{47}$

As temperature goes up, $\mathrm{N}_{0-2}$ content gradually decreases for SP and NS, while $\mathrm{N}_{3-5}$ content gradually increases; thus, $\mathrm{N}_{0-2}$ components may polymerize to form $\mathrm{N}_{3-5}$ components. However, for EP, $\mathrm{N}_{2}$ and $\mathrm{N}_{4}$ components decrease, and the other components increase at $300-600{ }^{\circ} \mathrm{C}$. It can be speculated that most $\mathrm{N}_{2}$ and $\mathrm{N}_{4}$ components are cracked into $\mathrm{N}_{0}, \mathrm{~N}_{1}$, and $\mathrm{N}_{3}$ components, and a few $\mathrm{N}_{0-4}$ components polymerize into $\mathrm{N}_{5}$ components. It is worth noting that the content of NCCs sharply increases from 600 to $700{ }^{\circ} \mathrm{C}$, and $\mathrm{N}_{1-4}$ components increase significantly. This is likely due to the secondary cracking reactions of pyridines, pyrroles, and indoles in char at high temperatures. ${ }^{43}$ In addition, the transformation of NCCs indicates that proteins and lipids in bio-oil are able to promote the formation of heavy components with high nitrogen numbers within a certain temperature range.

Figure 4 describes the relationship between the N/C ratio and the molecular weight of the heavy components in bio-oils; this illustrates how nitrogen is incorporated into molecules of different sizes. Most NCCs in these samples have a molecular weight between 200 and $400 \mathrm{Da}$ and a N/C ratio between 0 and 0.3. The maximum molecular weight can reach up to 800 $\mathrm{Da}$, and the molecular weights of components with the highest $\mathrm{N} / \mathrm{C}$ ratio are within 200-300 Da. As temperature increases, the molecular weight of NCCs gradually decreases, which indicates that NCCs also undergo decomposition in addition to the polymerization described above. Besides, the components with a larger $\mathrm{N} / \mathrm{C}$ ratio $(0.3-0.5)$ in $\mathrm{SP}$ and NS gradually increase, but the corresponding molecular weight does not change. It can be considered that nitrogen is accumulated into the compounds with a molecular weight of 200-300 Da.

3.4. Van Krevelen Diagrams. Van Krevelen diagrams can provide an overall view on the types of compounds in the pyrolysis bio-oil. $^{48,49}$ All the heavy components identified via positive ESI at 300 and $700{ }^{\circ} \mathrm{C}$ are presented in Figure 5, and 


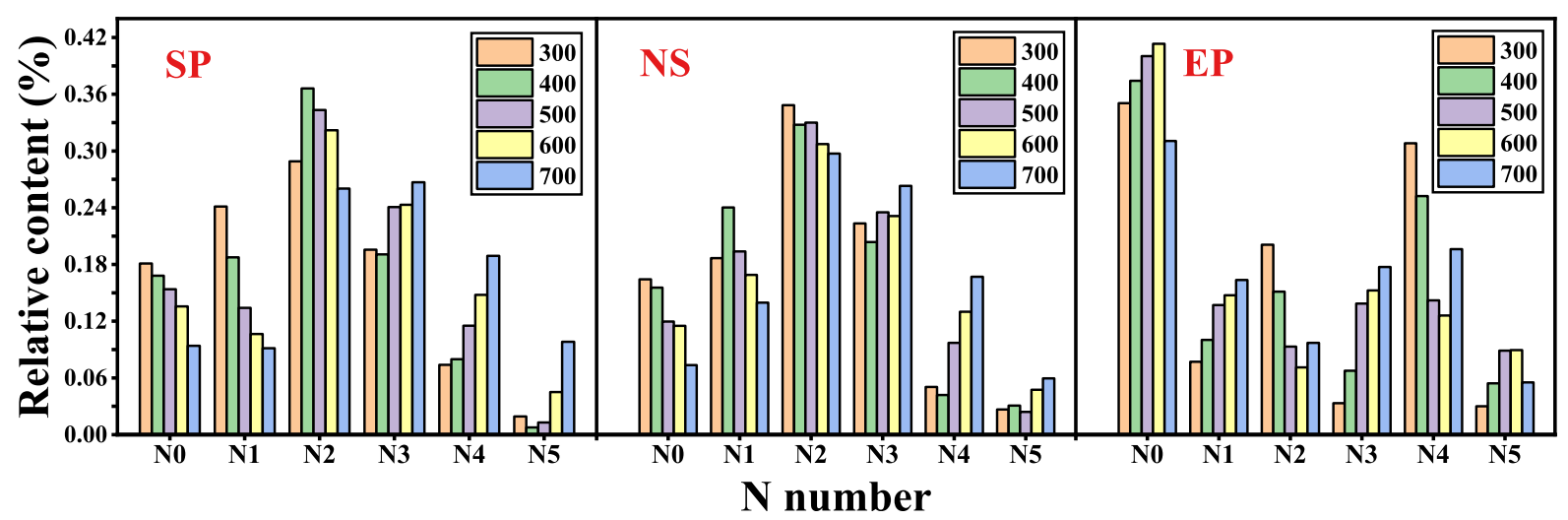

Figure 3. Relative content of heavy components with different NNs.

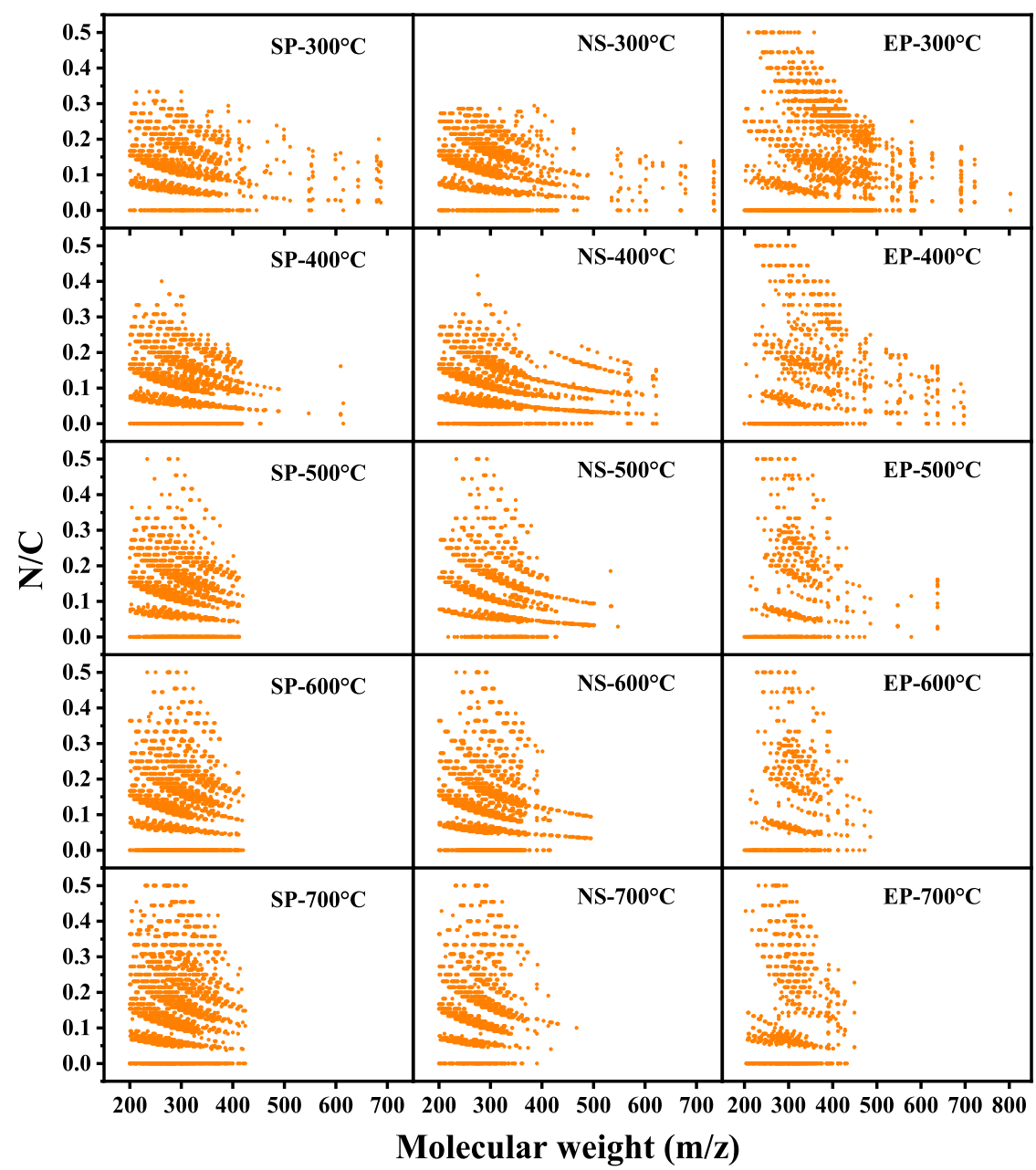

Figure 4. Relationship between N/C ratio and molecular weight.

the other van Krevelen diagrams are provided in Figure S4. These components are divided into four categories according to the differences in heteroatom composition (only $\mathrm{N}$ and $\mathrm{S}$ atoms are considered), and they are displayed in figures with different colors.

Previous studies have concluded that compounds (such as lignin, lipids, and so forth) are distributed in specific areas on the van Krevelen diagram. ${ }^{50,51}$ In this study, regions are defined according to the characteristics of heavy components in bio-oil and the definitions in previous literature studies. Each van Krevelen diagram is separated into six discrete regions to represent six major biomolecular groups of lipids (0 $\leq \mathrm{O} / \mathrm{C} \leq 0.2,1.7 \leq \mathrm{H} / \mathrm{C} \leq 2.25)$, peptides $(0.2<\mathrm{O} / \mathrm{C}<0.6$, $1.5<\mathrm{H} / \mathrm{C}<2.25, \mathrm{~N} / \mathrm{C}>0.05)$, carbohydrates $(0.6 \leq \mathrm{O} / \mathrm{C} \leq$ $1.2,1.5 \leq \mathrm{H} / \mathrm{C} \leq 2.2)$, lignin $(0.1<\mathrm{O} / \mathrm{C} \leq 0.6,0.5<\mathrm{H} / \mathrm{C}<$ 1.7, $\mathrm{AI}<0.67)$, unsaturated hydrocarbons $(0 \leq \mathrm{O} / \mathrm{C} \leq 0.1,0.7$ $\leq \mathrm{H} / \mathrm{C}<1.7)$ and condensed aromatics $(0 \leq \mathrm{O} / \mathrm{C} \leq 1.0,0.3$ $\leq \mathrm{H} / \mathrm{C} \leq 0.7, \mathrm{AI} \geq 0.67){ }^{52,53}$ Table 3 lists the relative abundance of these molecular compound classes under different temperatures, and the calculation method can refer to eq 4. The modified aromaticity index considering the 


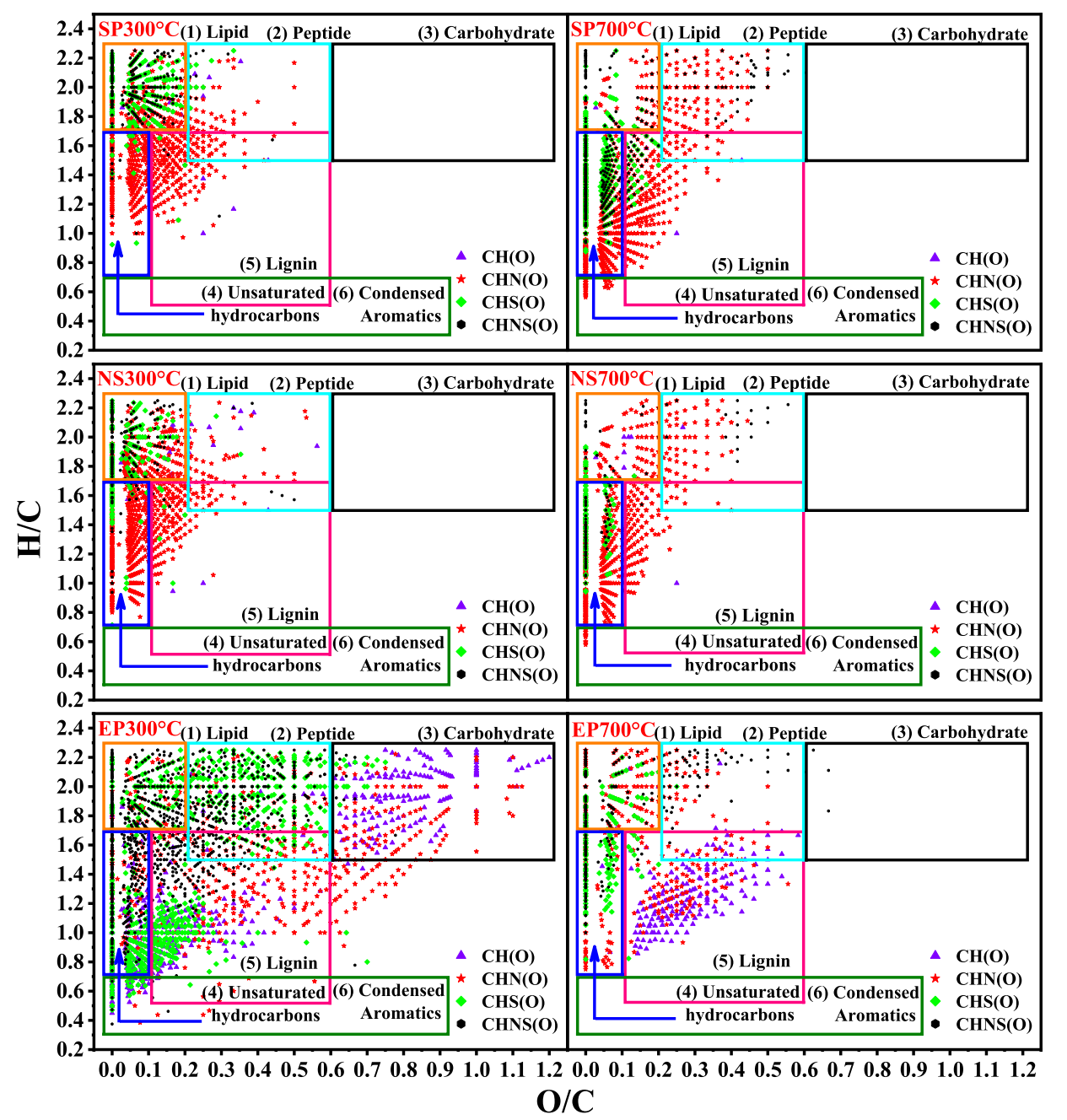

Figure 5. Van Krevelen diagrams of heavy components produced at 300 and $700{ }^{\circ} \mathrm{C}$.

Table 3. Relative Content of Different $\mathrm{N}_{X} \mathrm{O}_{Y}$ Groups in Heavy Components of Bio-Oil ${ }^{a}$

\begin{tabular}{|c|c|c|c|c|c|c|c|c|c|c|c|c|c|}
\hline \multirow[b]{2}{*}{ samples } & \multirow[b]{2}{*}{$T\left({ }^{\circ} \mathrm{C}\right)$} & \multirow[b]{2}{*}{$\mathrm{N}_{1}$} & \multirow[b]{2}{*}{$\mathrm{N}_{1} \mathrm{O}_{1}$} & \multirow[b]{2}{*}{$\mathrm{N}_{1} \mathrm{O}_{2}$} & \multirow[b]{2}{*}{$\mathrm{N}_{1} \mathrm{O}_{3}$} & \multicolumn{4}{|c|}{$\mathrm{N}_{2} \mathrm{O}_{X}(\%)$} & \multicolumn{4}{|c|}{$\mathrm{N}_{Y} \mathrm{O}_{X}(\%)$} \\
\hline & & & & & & $\mathrm{N}_{2}$ & $\mathrm{~N}_{2} \mathrm{O}$ & $\mathrm{N}_{2} \mathrm{O}_{2}$ & $\mathrm{~N}_{2} \mathrm{O}_{3}$ & $\mathrm{~N}_{Y}$ & $\mathrm{~N}_{\mathrm{Y}} \mathrm{O}$ & $\mathrm{N}_{Y} \mathrm{O}_{2}$ & $\mathrm{~N}_{Y} \mathrm{O}_{3}$ \\
\hline \multirow[t]{5}{*}{$\mathrm{SP}^{b}$} & 300 & 3.13 & 9.69 & 9.01 & 2.78 & 6.28 & 9.47 & 8.26 & 3.97 & 1.60 & 6.61 & 6.56 & 3.72 \\
\hline & 400 & 4.55 & 7.48 & 1.64 & 0.55 & 14.61 & 10.19 & 5.74 & 2.29 & 4.13 & 8.32 & 5.03 & 1.98 \\
\hline & 500 & 4.54 & 5.46 & 1.44 & 0.18 & 15.79 & 9.48 & 5.64 & 2.10 & 6.80 & 9.37 & 5.81 & 2.11 \\
\hline & 600 & 4.71 & 4.31 & 1.24 & 0.00 & 18.07 & 8.30 & 4.49 & 1.07 & 8.83 & 9.23 & 4.91 & 1.29 \\
\hline & 700 & 4.78 & 4.33 & 1.79 & 0.23 & 12.23 & 7.00 & 3.32 & 1.06 & 10.25 & 6.88 & 4.98 & 2.10 \\
\hline \multirow[t]{5}{*}{$\mathrm{NS}^{b}$} & 300 & 5.50 & 5.64 & 3.43 & 1.38 & 16.31 & 9.86 & 6.56 & 2.22 & 6.23 & 9.32 & 5.49 & 1.95 \\
\hline & 400 & 5.19 & 7.97 & 4.76 & 1.48 & 12.53 & 8.69 & 3.42 & 0.92 & 4.33 & 11.45 & 3.10 & 1.54 \\
\hline & 500 & 5.58 & 7.12 & 2.03 & 0.56 & 19.15 & 8.76 & 3.72 & 0.83 & 7.65 & 10.50 & 4.04 & 1.22 \\
\hline & 600 & 6.69 & 3.22 & 1.26 & 1.54 & 18.83 & 6.33 & 2.95 & 0.66 & 8.58 & 8.05 & 2.90 & 0.15 \\
\hline & 700 & 5.69 & 5.19 & 0.81 & 0.22 & 18.77 & 7.70 & 4.07 & 0.57 & 11.44 & 8.54 & 5.40 & 0.67 \\
\hline \multirow[t]{5}{*}{$\mathrm{EP}^{c}$} & 300 & 0.76 & 1.04 & 0.90 & 0.44 & 2.37 & 2.67 & 3.34 & 3.62 & 2.87 & 3.96 & 3.99 & 3.01 \\
\hline & 400 & 3.51 & 3.07 & 1.07 & 0.73 & 4.77 & 3.44 & 2.56 & 1.50 & 3.97 & 3.05 & 1.16 & 0.61 \\
\hline & 500 & 6.91 & 4.34 & 0.67 & 0.38 & 4.15 & 2.63 & 1.04 & 0.62 & 5.74 & 1.76 & 0.28 & 0.61 \\
\hline & 600 & 4.91 & 1.82 & 0.16 & 1.03 & 4.09 & 0.41 & 0.35 & 0.51 & 7.44 & 1.87 & 0.92 & 0.70 \\
\hline & 700 & 5.42 & 2.97 & 0.33 & 1.58 & 7.38 & 0.51 & 0.42 & 1.48 & 9.71 & 3.66 & 2.21 & 1.37 \\
\hline
\end{tabular}

${ }^{a} T$, temperature. ${ }^{b} \mathrm{~N}_{Y} \mathrm{O}_{X}$ represents $\mathrm{N}_{3} \mathrm{O}_{X} \cdot{ }^{c} \mathrm{~N}_{Y} \mathrm{O}_{X}$ represents $\mathrm{N}_{4} \mathrm{O}_{X}$.

contribution of $\pi$-bonds by heteroatoms and $\mathrm{O}, \mathrm{AI}$, is calculated by eq $5^{54}$

$$
\mathrm{AI}=(1+\mathrm{C}-0.5 \mathrm{O}-\mathrm{S}-0.5 \mathrm{H}) /(\mathrm{C}-0.5 \mathrm{O}-\mathrm{S}-\mathrm{N}-\mathrm{P})
$$

where $\mathrm{C}, \mathrm{H}, \mathrm{O}, \mathrm{N}, \mathrm{S}$, and $\mathrm{P}$ represent the atom number.
Obviously, the heavy components in these bio-oils show significantly different van Krevelen diagrams, as shown in Figure 5. For SP and NS, almost all molecular formulas distribute in the region with $\mathrm{O} / \mathrm{C}<0.6$, and no carbohydratelike compounds exist. For EP, there are some components $(\mathrm{O} /$ 

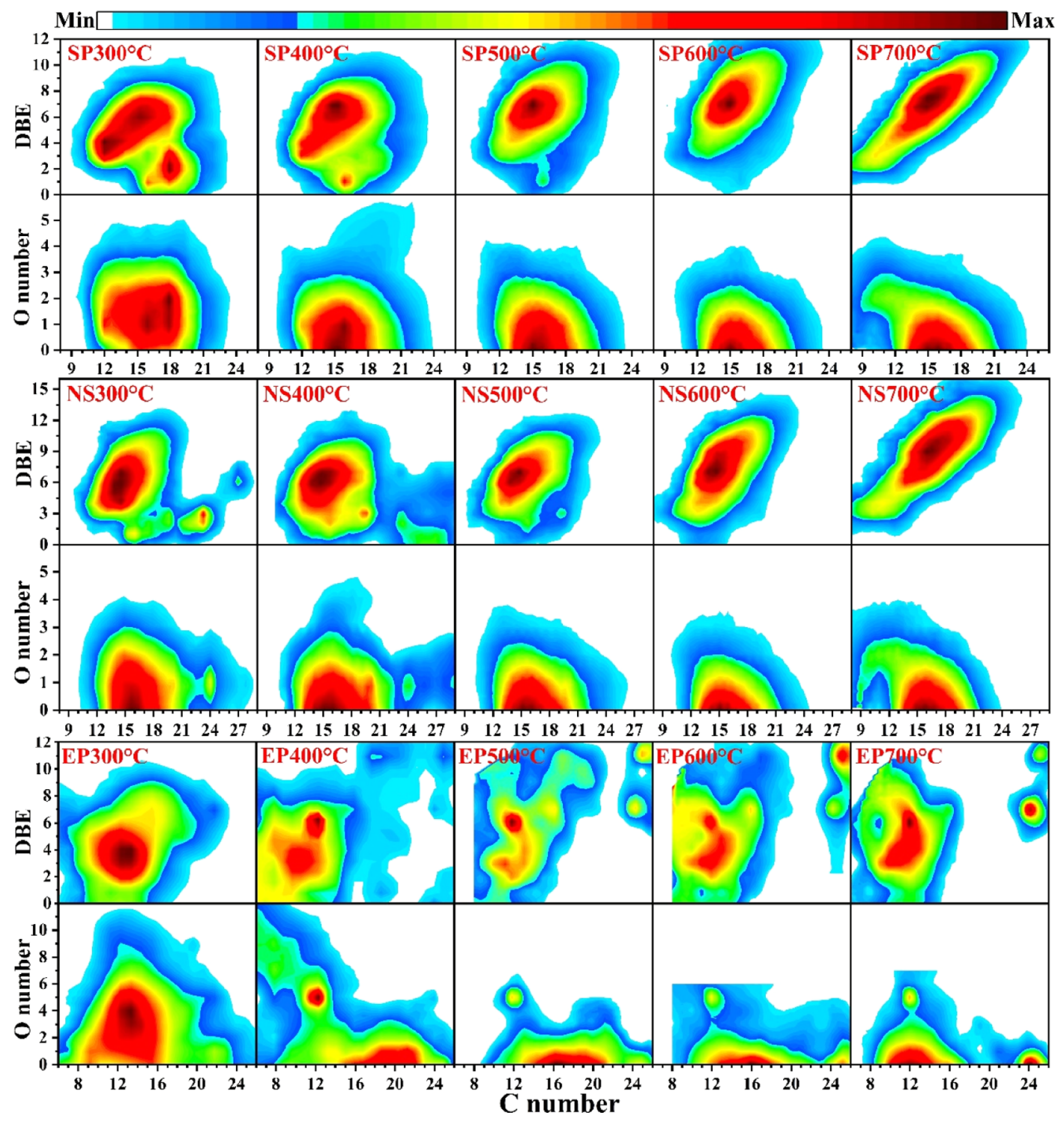

Figure 6. Contour plots of the heavy NCCs under different temperatures.

$\mathrm{C} \geq 0.6)$ which distribute in the carbohydrate-like region at lower temperatures $\left(300-400{ }^{\circ} \mathrm{C}\right)$. This is mainly due to the high carbohydrate content in the EP feedstock, which also explains the higher $\mathrm{AO} / \mathrm{C}$ ratio of EP shown in Table 2. It should be noted that the carbohydrate content in EP gradually decreases as the temperature increases, reaching a low value of $1.93 \%$ at $500{ }^{\circ} \mathrm{C}$. Anastasakis and Wei et al. ${ }^{55,56}$ found that the weight loss of carbohydrates basically reached its maximum value when the temperature exceeded $500{ }^{\circ} \mathrm{C}$. This implies that the carbohydrates are completely thermally degraded at $500{ }^{\circ} \mathrm{C}$, which is consistent with the results above.

It can be found from Table S2 that the unsaturated hydrocarbon-like compounds derived from SP and NS increase with the increase of temperature. A small amount of condensed aromatic-like compounds begins to appear at $700{ }^{\circ} \mathrm{C}$, corresponding to the decrease in the $\mathrm{AH} / \mathrm{C}$ shown in Table 2. However, the trend is much different for EP, does not change significantly for the unsaturated hydrocarbon-like compounds, and gradually declines for the condensed aromatic-like compounds. This result may suggest that lipids and proteins make noticeable contribution to the formation of unsaturated hydrocarbon-like compounds in heavy components at higher temperatures $\left(\geq 500{ }^{\circ} \mathrm{C}\right) .{ }^{57}$

On the other hand, it can be found (Figures 5 and S4) that most $\mathrm{CHNS}(\mathrm{O})$ components (black dots) distribute in the lipid-like and unsaturated hydrocarbon-like regions, while most $\mathrm{CHN}(\mathrm{O})$ components (red dots) fall in the lignin-like and lipid-like regions for SP and NS. This is roughly the same as the rules obtained by $\mathrm{He}$ et al. $^{52}$ In comparison, the distribution of NCCs (red and black dots) from EP is more diverse. Overall, as temperature increases, most CHNS $(\mathrm{O})$ compounds tend to converge toward lipid-like and unsaturated hydrocarbon-like regions. In addition, $\mathrm{CH}(\mathrm{O})$ and $\mathrm{CHN}(\mathrm{O})$ compounds tend to shift from the diffusion points with $\mathrm{O} / \mathrm{C}=$ $1, \mathrm{H} / \mathrm{C}=2$ to the diffusion points with $\mathrm{O} / \mathrm{C}=0, \mathrm{H} / \mathrm{C}=2$ and $\mathrm{O} / \mathrm{C} \approx 0.33, \mathrm{H} / \mathrm{C} \approx 1.33$. Hu et al. ${ }^{39}$ found similar diffusion points in the study of NCCs and considered that different lines stretching from the diffusion point corresponded to the compound losing or gaining certain groups. Therefore, it is reasonable to believe that the main reactions occurring during the heating process are different for the $\mathrm{CH}(\mathrm{O})$ and $\mathrm{CHN}(\mathrm{O})$ components. 


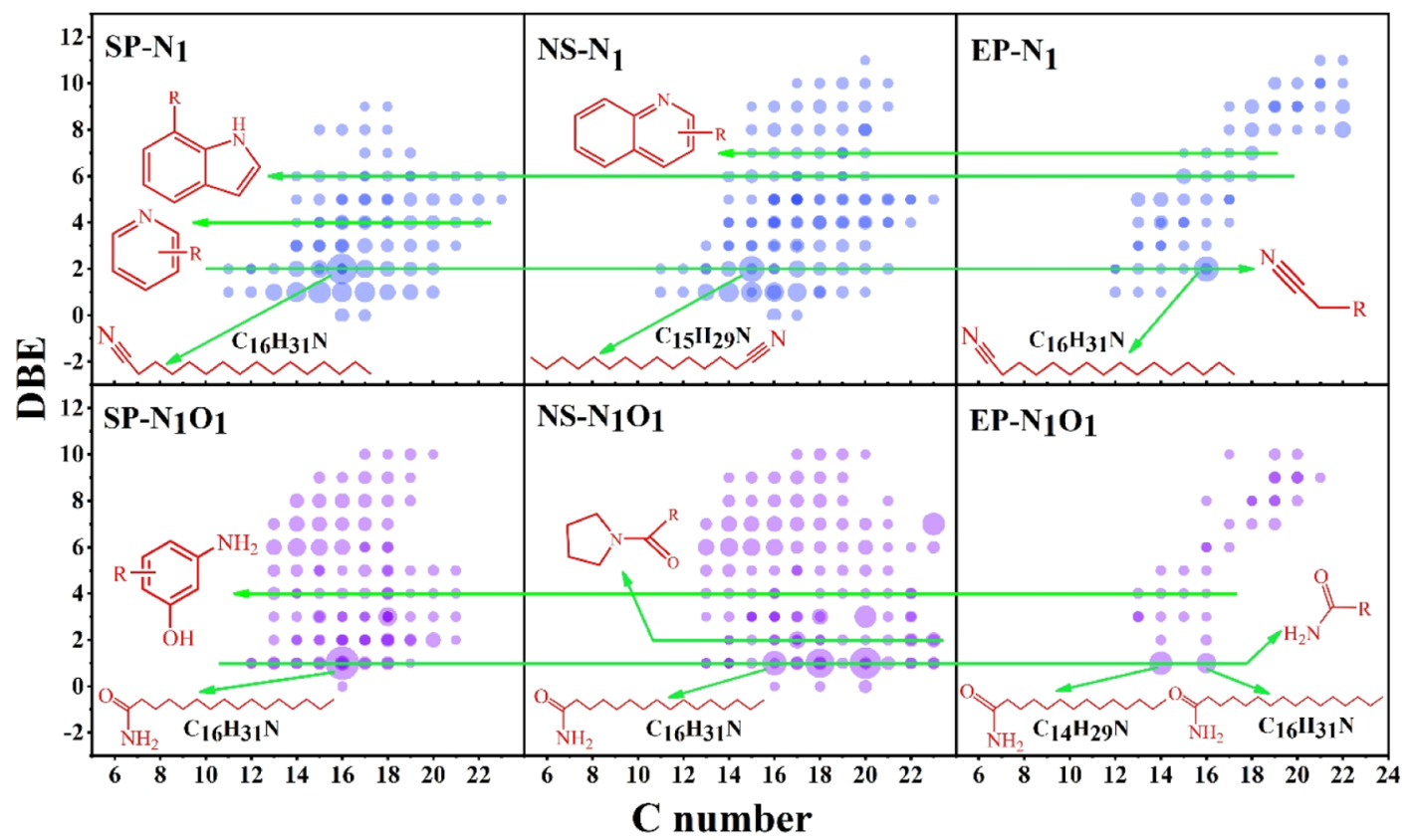

Figure 7. Bubble diagrams of $\mathrm{DBE}$ vs $\mathrm{CN}$ for $\mathrm{N}_{1}$ and $\mathrm{N}_{1} \mathrm{O}_{1}$ species.

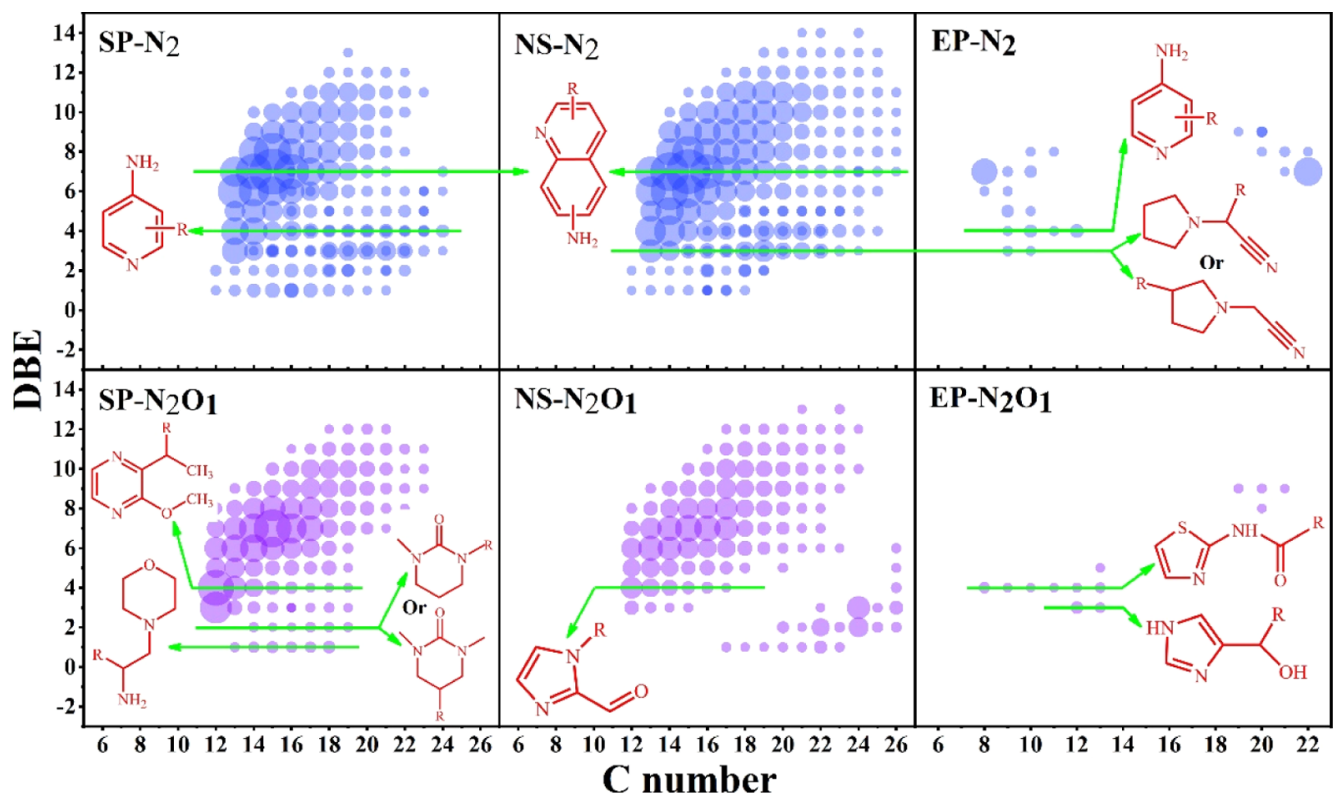

Figure 8. Bubble diagrams of $\mathrm{DBE}$ vs $\mathrm{CN}$ for $\mathrm{N}_{2}$ and $\mathrm{N}_{2} \mathrm{O}_{1}$ species.

3.5. Potential Structure of Heavy NCCs. Structural details of NCCs are further understood through the twodimensional contour plots of $\mathrm{DBE}$ versus $\mathrm{C}$ number $(\mathrm{CN})$ or $\mathrm{O}$ numbers $(\mathrm{ON})$ versus $\mathrm{CN}$. A cyclane ring or double bond can increase one DBE value, and three or four DBE increments may be due to the introduction of a benzene ring condensed with the core structure of the heavy compounds or connected to the core structure by bridged linkage. ${ }^{40}$ Furthermore, the $\mathrm{O}$ atoms in NCCs may appear in ester, amide, hydroxy, carbonyl, and alkoxy groups, ${ }^{16}$ and components that differ only in $\mathrm{CH}_{2}$ group numbers may be homologous compounds.

The contour plots of the heavy NCCs under different temperatures are presented in Figure 6, and the color code in these plots represents the sum of the relative abundances of components within the specific class. The plots of SP and NS are ordered, while that of EP is relatively disordered due to the low content of NCCs. Roughly speaking, the peaks of SP (NS, $\mathrm{EP})$ are characterized by $\mathrm{DBE}=4-10(3-8,3-6), \mathrm{ON}=0-1$ $(0-2,0-5)$, and $\mathrm{CN}=13-18(11-16,11-16)$. Besides, as temperature increases, all the peaks shift toward larger DBE values (>4) and less $\mathrm{ON}$ (especially at $300-500{ }^{\circ} \mathrm{C}$ ) regions, but the corresponding $\mathrm{CN}$ changes little. Most heavy NCCs become more aromatic and contain less $\mathrm{O}$. This may result from the strong Maillard, decarboxylation, and deoxygenation reactions at higher temperatures. ${ }^{13,58}$

According to the number of nitrogen and oxygen atoms, the heavy NCCs are divided into different species such as $\mathrm{N}_{1} \mathrm{O}_{1}$, $\mathrm{N}_{2} \mathrm{O}_{1}$, and so forth, and the contents of these species calculated with reference to eq 4 are listed in Table 3. At different temperatures, the main components of different 


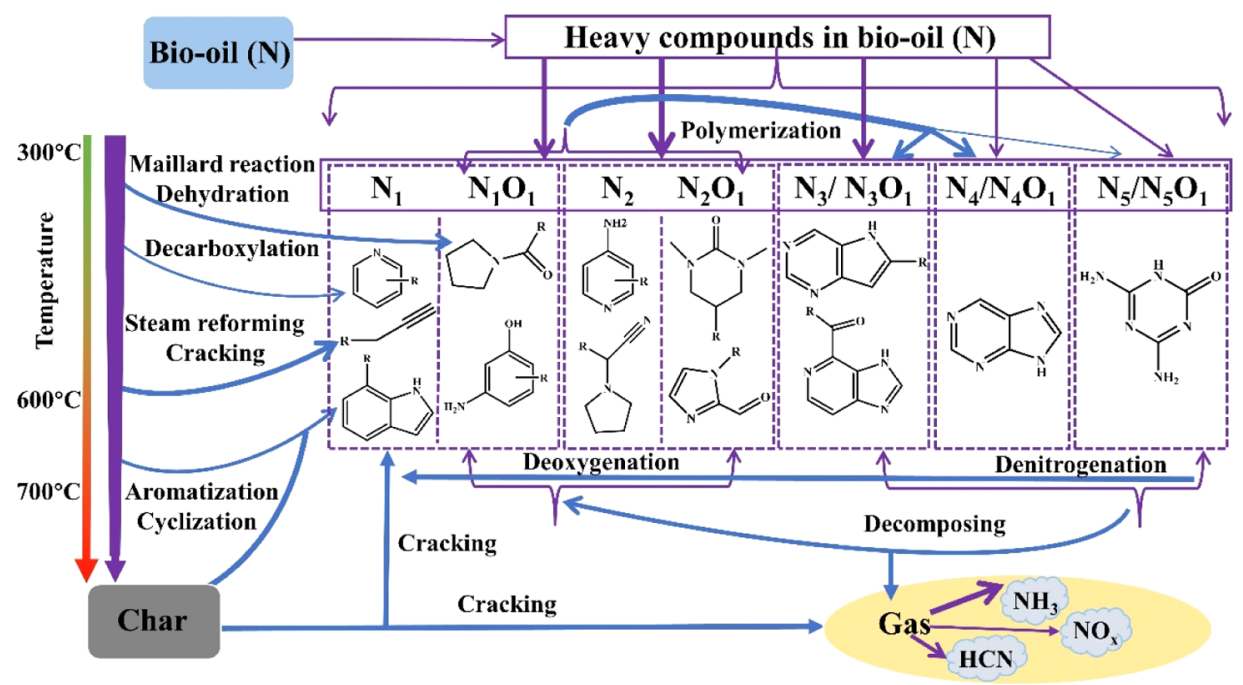

Figure 9. Evolution routes of nitrogen in heavy bio-oil compounds for N-rich feedstocks (purple line: bio-oil or gas composition, blue line: reaction pathway, and line width: content or intensity).

$\mathrm{N}_{\mathrm{Y}} \mathrm{O}_{\mathrm{X}}$ class species are generally $\mathrm{N}_{\mathrm{Y}}$ and $\mathrm{N}_{\mathrm{Y}} \mathrm{O}_{1}$ species, such as $\mathrm{N}_{1}, \mathrm{~N}_{1} \mathrm{O}_{1}, \mathrm{~N}_{2}, \mathrm{~N}_{2} \mathrm{O}_{1}$, and so forth. Considering that the bio-oil yields are high at $500{ }^{\circ} \mathrm{C}$ and the total nitrogen abundance is different, diverse $\mathrm{N}_{Y}$ and $\mathrm{N}_{Y} \mathrm{O}_{1}$ species at $500{ }^{\circ} \mathrm{C}$ are selected for the potential structure analysis. Besides, some NCCs (shown in Table S3) tested by GC-MS are used to assist in verification.

3.5.1. $N_{1}$ and $N_{1} O_{1}$ Species. As exhibited in Figure 7, the $\mathrm{DBE}$ value and $\mathrm{CN}$ for most of the $\mathrm{N}_{1}$ and $\mathrm{N}_{1} \mathrm{Ox}$ species range from 0 to 10 and from 13 to 22 , respectively. However, compounds with $\mathrm{DBE}<7$ and $\mathrm{C}>17$ are not found in $\mathrm{N}_{1}$ and $\mathrm{N}_{1} \mathrm{O}_{1}$ species of EP. These components may consist of pyridine ring/amines, an aromatic or aliphatic ring, and/or long alkyl side chains. ${ }^{59}$ Hexadecanenitrile- $\mathrm{C}_{16} \mathrm{H}_{31} \mathrm{~N}$ or pentadecanenitrile- $\mathrm{C}_{15} \mathrm{H}_{29} \mathrm{~N}$ is detected in $\mathrm{GC}-\mathrm{MS}$ and shows high abundance in FT-ICR-MS for all samples at 500 ${ }^{\circ} \mathrm{C}$; thus, the $\mathrm{N}_{1}$ species with $\mathrm{DBE}=2$ may refer to the homologue of nitriles. 7-Methylindole- $\mathrm{C}_{9} \mathrm{H}_{9} \mathrm{~N}$ and quinoline$\mathrm{C}_{9} \mathrm{H}_{7} \mathrm{~N}$ compounds are also found, and compounds with DBE $=6$ in all samples and $\mathrm{DBE}=7$ in NS and $\mathrm{EP}$ may be homologues of indoles and quinolines, which are mainly derived from cyclization and aromatization. ${ }^{22}$ Similarly, compounds with $\mathrm{DBE}=1$ may attribute to long-chain alkylamine due to the presence of hexadecanamide$\mathrm{C}_{16} \mathrm{H}_{33} \mathrm{NO}$ and tetradecanamide- $\mathrm{C}_{14} \mathrm{H}_{29} \mathrm{NO}$ in $\mathrm{N}_{1} \mathrm{O}_{1}$ species.

3.5.2. $\mathrm{N}_{2}-\mathrm{N}_{4}$ and $\mathrm{N}_{2} \mathrm{O}_{1}-\mathrm{N}_{4} \mathrm{O}_{1}$ Species. Figure 8 shows the structural information of $\mathrm{N}_{2}$ and $\mathrm{N}_{2} \mathrm{O}_{1}$ species. The DBE range $(1-14)$ of $\mathrm{N}_{2} / \mathrm{N}_{2} \mathrm{O}_{1}$ species in NS and SP is similar, but NS shows a wider range (12-26) in $\mathrm{CN}$ than SP (12-23). The most abundant $\mathrm{N}_{2}$ compounds (the large circles) with the same DBE value may be different homologues in different samples because 2-ethyl-3-methoxypyrazine and 2-acetamidothiazole with $\mathrm{DBE}=4$ are detected in SP and NS, respectively. EP contains very few $\mathrm{N}_{2} / \mathrm{N}_{2} \mathrm{O}_{1}$ compounds, the $\mathrm{DBE}$ values of which are lower than 10 , indicating that there are up to two aromatic rings in $\mathrm{N}_{2} / \mathrm{N}_{2} \mathrm{O}_{1}$ species. The $\mathrm{GC}-\mathrm{MS}$ results show that these species may be composed of pyridine ring/pyrrole ring/amines, acetonitrile or imidazole, hydroxyl/carboxyl groups, and/or alkyl side chains.

Figure S6 shows the relationship between DBE and CN of the $\mathrm{N}_{3} / \mathrm{N}_{4}$ and $\mathrm{N}_{3} \mathrm{O}_{1} / \mathrm{N}_{4} \mathrm{O}_{1}$ species. For SP and NS, most $\mathrm{N}_{3}$ species distribute in the range of $\mathrm{DBE}=4-14$ and $\mathrm{CN}=11-$
25, while the $\mathrm{N}_{3} \mathrm{O}_{1}$ species have a wider $\mathrm{C}$ number range from 11 to 33. For EP, the $\mathrm{N}_{4} \mathrm{O}_{1}$ compounds are significantly less than $\mathrm{N}_{4}$ compounds in content and contain at most one aromatic ring because the DBE value is less than 5. Notably, GC-MS detects very few components containing 3-4 Natoms because the compounds with high $\mathrm{N}$ numbers are less volatile. This result also reflects the necessity of using FT-ICRMS to analyze the heavy NCCs.

3.6. Evolution Routes of Nitrogen in Heavy Bio-Oil Compounds. The possible evolution routes of nitrogen in the heavy components of bio-oil generated from the pyrolysis of $\mathrm{N}$-rich algae (SP and NS) are proposed (Figure 9) based on the above discussions. $\mathrm{N}_{1-3}$ components are the prominent compounds in the heavy components, and among these $\mathrm{N}_{1-3}$ components, $\mathrm{N}_{Y}$ and $\mathrm{N}_{Y} \mathrm{O}_{1}$ (such as $\mathrm{N}_{1}, \mathrm{~N}_{1} \mathrm{O}_{1}, \mathrm{~N}_{2}$, and so forth) species are dominant. At $300-700{ }^{\circ} \mathrm{C}, \mathrm{N}_{1-2}$ and $\mathrm{N}_{3-5}$ components will undergo polymerization and decomposition reactions, respectively, but the condensation reaction is much stronger, resulting in an increase in the heavy components with more $\mathrm{N}$-atoms at higher temperatures. The decomposition mainly includes denitrogenation and deoxygenation, which can produce a large amount of harmful $\mathrm{NH}_{3}$ (mainly), $\mathrm{HCN}$, and NO gases. The heating process during pyrolysis is accompanied by the Maillard, dehydration, decarboxylation, cracking, steam reforming, cyclization, and aromatization reactions, leading to the formation of a variety of complex chemicals in the heavy components of bio-oil (such as nitriles, amides, and heterocyclic N) and char.

3.7. Strategies for Producing High-Quality Bio-Oil. In this study, the composition characteristics and evolution routes of nitrogen in bio-oil derived from algae pyrolysis are further investigated. Based on these results, strategies for producing high-quality bio-oil can be proposed. It is recommended to obtain nitriles and alkylamine-rich pyrolysis bio-oil from lipids and protein-rich algae (e.g., SP) at $400-600{ }^{\circ} \mathrm{C}$. These nitriles and alkylamines (C14-C16) occupy a high proportion (up to $51.8 \%$ ) of the NCCs and are more friendly to bio-oil upgrading and diesel preparation because nitrile and amide functional groups can be easily removed in the hydrogenation process. ${ }^{60}$ Carbohydrate-rich algae are suggested to produce the highest bio-oil yield at $500{ }^{\circ} \mathrm{C}$, at which temperature the content of NCCs in both light and heavy components is low. Besides, 
pyrroles and pyridines account for $45 \%$ of the NCCs and can be further removed from bio-oil by the metal-supported HZSM-5 catalyst. $^{61}$
Science Foundation of China (52076098), and the International Cooperation Project of Shenzhen (GJHZ20190820102607238). There are no conflicts to declare.

\section{REFERENCES}

(1) Sekar, M.; Mathimani, T.; Alagumalai, A.; Chi, N. T. L.; Duc, P. A.; Bhatia, S. K.; Brindhadevi, K.; Pugazhendhi, A. A review on the pyrolysis of algal biomass for biochar and bio-oil - Bottlenecks and scope. Fuel 2021, 283, 119190.

(2) Zabed, H. M.; Akter, S.; Yun, J.; Zhang, G.; Awad, F. N.; Qi, X.; Sahu, J. N. Recent advances in biological pretreatment of microalgae and lignocellulosic biomass for biofuel production. Renew. Sustain. Energy Rev. 2019, 105, 105-128.

(3) Serrano-Ruiz, J. C.; Dumesic, J. A. Catalytic routes for the conversion of biomass into liquid hydrocarbon transportation fuels. Energy Environ. Sci. 2011, 4, 83-99.

(4) Huber, G. W.; Iborra, S.; Corma, A. Synthesis of transportation fuels from biomass: Chemistry, catalysts, and engineering. Chem. Rev. 2006, 106, 4044-4098.

(5) Chaiwong, K.; Kiatsiriroat, T.; Vorayos, N.; Thararax, C. Study of bio-oil and bio-char production from algae by slow pyrolysis. Biomass Bioenergy 2013, 56, 600-606.

(6) Leng, L.; Yang, L.; Chen, J.; Leng, S.; Li, H.; Li, H.; Yuan, X.; Zhou, W.; Huang, H. A review on pyrolysis of protein-rich biomass: Nitrogen transformation. Bioresour. Technol. 2020, 315, 123801.

(7) Higasio, Y. S.; Shoji, T. Heterocyclic compounds such as pyrroles, pyridines, pyrollidins, piperdines, indoles, imidazol and pyrazins. Appl. Catal., A 2001, 221, 197-207.

(8) Zhan, H.; Zhuang, X.; Song, Y.; Yin, X.; Wu, C. Insights into the evolution of fuel-N to $\mathrm{NO}$ precursors during pyrolysis of $\mathrm{N}$-rich nonlignocellulosic biomass. Appl. Energy 2018, 219, 20-33.

(9) Xiong, Z.; Guo, J.; Chaiwat, W.; Deng, W.; Hu, X.; Han, H.; Chen, Y.; Xu, K.; Su, S.; Hu, S.; Wang, Y.; Xiang, J. Assessing the chemical composition of heavy components in bio-oils from the pyrolysis of cellulose, hemicellulose and lignin at slow and fast heating rates. Fuel Process. Technol. 2020, 199, 106299.

(10) Xiong, Z.; Han, H.; Azis, M. M.; Hu, X.; Wang, Y.; Su, S.; Hu, S.; Xiang, J. Formation of the heavy tar during bio-oil pyrolysis: A study based on Fourier transform ion cyclotron resonance mass spectrometry. Fuel 2019, 239, 108-116.

(11) Niu, Q.; Wang, J.; Cao, C.; Cheng, Z.; Zhu, Y.; Wen, W.; Wang, J.; Pan, Y.; Yan, B.; Chen, G.; Ronsse, F. Comparative study of different algae pyrolysis using photoionization mass spectrometry and gas chromatography/mass spectrometry. J. Anal. Appl. Pyrol. 2021, $155,105068$.

(12) Ba, T.; Chaala, A.; Garcia-Perez, M.; Roy, C. Colloidal Properties of Bio-Oils Obtained by Vacuum Pyrolysis of Softwood Bark. Storage Stability. Energy Fuels 2004, 18, 188-201.

(13) Chen, W.; Yang, H.; Chen, Y.; Xia, M.; Yang, Z.; Wang, X.; Chen, H. Algae pyrolytic poly-generation: Influence of component difference and temperature on products characteristics. Energy 2017, $131,1-12$.

(14) Campanella, A.; Harold, M. P. Fast pyrolysis of microalgae in a falling solids reactor: Effects of process variables and zeolite catalysts. Biomass Bioenergy 2012, 46, 218-232.

(15) Mullen, C. A.; Strahan, G. D.; Boateng, A. A. Characterization of Various Fast-Pyrolysis Bio-Oils by NMR Spectroscopy†. Energy Fuels 2009, 23, 2707-2718.

(16) Liu, Y.; Shi, Q.; Zhang, Y.; He, Y.; Chung, K. H.; Zhao, S.; Xu, C. Characterization of Red Pine Pyrolysis Bio-oil by Gas Chromatography-Mass Spectrometry and Negative-Ion Electrospray Ionization Fourier Transform Ion Cyclotron Resonance Mass Spectrometry. Energy Fuels 2012, 26, 4532-4539.

(17) Sudasinghe, N.; Dungan, B.; Lammers, P.; Albrecht, K.; Elliott, D.; Hallen, R.; Schaub, T. High resolution FT-ICR mass spectral analysis of bio-oil and residual water soluble organics produced by

\footnotetext{
The authors acknowledge funding from the National Key R\&D Program of China (2017YFE0124200), the National Natural

Author Contributions
${ }^{\perp}$ J.L. and Z.X. are co-first authors.

Notes

The authors declare no competing financial interest.

\section{ACKNOWLEDGMENTS}


hydrothermal liquefaction of the marine microalga Nannochloropsis salina. Fuel 2014, 119, 47-56.

(18) Wang, J.; Hao, Z.; Shi, F.; Yin, Y.; Cao, D.; Yao, Z.; Liu, J. Characterization of brominated disinfection byproducts formed during the chlorination of aquaculture seawater. Environ. Sci. Technol. 2018, 52, 5662-5670.

(19) Pourkarimi, S.; Hallajisani, A.; Alizadehdakhel, A.; Nouralishahi, A. Biofuel production through micro- and macroalgae pyrolysis - A review of pyrolysis methods and process parameters. $J$. Anal. Appl. Pyrol. 2019, 142, 104599.

(20) Li, R.; Zhong, Z.; Jin, B.; Zheng, A. Selection of Temperature for Bio-oil Production from Pyrolysis of Algae from Lake Blooms. Energy Fuels 2012, 26, 2996-3002.

(21) Gong, X.; Zhang, B.; Zhang, Y.; Huang, Y.; Xu, M. Investigation on Pyrolysis of Low Lipid Microalgae Chlorella vulgaris and Dunaliella salina. Energy Fuels 2014, 28, 95-103.

(22) Du, Z.; Hu, B.; Ma, X.; Cheng, Y.; Liu, Y.; Lin, X.; Wan, Y.; Lei, H.; Chen, P.; Ruan, R. Catalytic pyrolysis of microalgae and their three major components: Carbohydrates, proteins, and lipids. Bioresour. Technol. 2013, 130, 777-782.

(23) Aysu, T.; Maroto-Valer, M. M.; Sanna, A. Ceria promoted deoxygenation and denitrogenation of Thalassiosira weissflogii and its model compounds by catalytic in-situ pyrolysis. Bioresour. Technol. 2016, 208, 140-148.

(24) Chen, P.; Min, M.; Chen, Y.; Liang, W.; Ruan, R. Review of biological and engineering aspects of algae to fuels approach. Int. J. Agric. Biol. Eng. 2010, 2, 1-30.

(25) Zhan, D.; Fenn, J. B. Electrospray mass spectrometry of fossil fuels. Int. J. Mass Spectrom. 2000, 194, 197-208.

(26) Koch, B. P.; Dittmar, T.; Witt, M.; Kattner, G. Fundamentals of molecular formula assignment to ultrahigh resolution mass data of natural organic matter. Anal. Chem. 2007, 79, 1758-1763.

(27) Cole, D. P.; Smith, E. A.; Dalluge, D.; Wilson, D. M.; Heaton, E. A.; Brown, R. C.; Lee, Y. J. Molecular characterization of nitrogencontaining species in switchgrass bio-oils at various harvest times. Fuel 2013, 111, 718-726.

(28) Staš, M.; Chudoba, J.; Auersvald, M.; Kubička, D.; Conrad, S.; Schulzke, T.; Pospísil, M. Application of orbitrap mass spectrometry for analysis of model bio-oil compounds and fast pyrolysis bio-oils from different biomass sources. J. Anal. Appl. Pyrol. 2017, 124, 230238.

(29) Jaggi, A.; Radović, J. R.; Snowdon, L. R.; Larter, S. R.; Oldenburg, T. B. P. Composition of the dissolved organic matter produced during in situ burning of spilled oil. Org. Geochem. 2019, $138,103926$.

(30) Kujawinski, E. B.; Longnecker, K.; Blough, N. V.; Vecchio, R. D.; Finlay, L.; Kitner, J. B.; Giovannoni, S. J. Identification of possible source markers in marine dissolved organic matter using ultrahigh resolution mass spectrometry. Geochim. Cosmochim. Acta 2009, 73, 4384-4399.

(31) Zeng, K.; Yang, Q.; Zhang, Y.; Mei, Y.; Wang, X.; Yang, H.; Shao, J.; Li, J.; Chen, $\mathrm{H}$. Influence of torrefaction with Mg-based additives on the pyrolysis of cotton stalk. Bioresour. Technol. 2018, 261, 62-69.

(32) Ohno, T.; Ohno, P. E. Influence of heteroatom pre-selection on the molecular formula assignment of soil organic matter components determined by ultrahigh resolution mass spectrometry. Anal. Bioanal. Chem. 2013, 405, 3299-3306.

(33) Koch, B. P.; Witt, M.; Engbrodt, R.; Dittmar, T.; Kattner, G. Molecular formulae of marine and terrigenous dissolved organic matter detected by electrospray ionization Fourier transform ion cyclotron resonance mass spectrometry. Geochim. Cosmochim. Acta 2005, 69, 3299-3308.

(34) Kujawinski, E. B.; Behn, M. D. Automated analysis of electrospray ionization Fourier transform ion cyclotron resonance mass spectra of natural organic matter. Anal. Chem. 2006, 78, 43634373.
(35) Hu, Z.; Zheng, Y.; Yan, F.; Xiao, B.; Liu, S. Bio-oil production through pyrolysis of blue-green algae blooms (BGAB): Product distribution and bio-oil characterization. Energy 2013, 52, 119-125.

(36) Jie, L.; Yuwen, L.; Jingyan, S.; Zhiyong, W.; Ling, H.; Xi, Y.; Cunxin, W. The investigation of thermal decomposition pathways of phenylalanine and tyrosine by TG-FTIR. Thermochim. Acta 2008, 467, 20-29.

(37) Belotti, G.; de Caprariis, B.; De Filippis, P.; Scarsella, M.; Verdone, N. Effect of Chlorella vulgaris growing conditions on bio-oil production via fast pyrolysis. Biomass Bioenergy 2014, 61, 187-195.

(38) Wang, X.; Sheng, L.; Yang, X. Pyrolysis characteristics and pathways of protein, lipid and carbohydrate isolated from microalgae Nannochloropsis sp. Bioresour. Technol. 2017, 229, 119-125.

(39) Hu, S.; Han, H.; Syed-Hassan, S. S. A.; Zhang, Y.; Wang, Y.; Zhang, L.; He, L.; Su, S.; Jiang, L.; Cheng, J.; Xiang, J. Evolution of heavy components during sewage sludge pyrolysis: A study using an electrospray ionization Fourier transform ion cyclotron resonance mass spectrometry. Fuel Process. Technol. 2018, 175, 97-103.

(40) Zhang, D.-D.; Zong, Z.-M.; Liu, J.; Lv, J.-H.; Wang, T.-M.; Gui, J.; Qu, M.; Guo, L.-L.; Feng, Z.-H.; Wei, X.-Y. Characterization of nitrogen- and oxygen-containing species in methanol-extractable portion from Xinghe lignite. Fuel Process. Technol. 2016, 142, 167173.

(41) Zhan, K.; Zong, Z.; Yan, H.; Wei, Z.; Li, Y.; Wei, X. Identification of basic nitrogen compounds in ethanol-soluble portion from Zhaotong lignite ethanolysis by positive-ion electrospray ionization Fourier transform ion cyclotron resonance mass spectrometry. Fuel 2014, 141, 268-274.

(42) Analytical pyrolysis of polymeric carbohydrates. In Techniques and Instrumentation in Analytical Chemistry; Moldoveanu, S. C., Ed.; Elsevier, 1998; chapter 7, pp 217-315.

(43) Chen, W.; Yang, H.; Chen, Y.; Xia, M.; Chen, X.; Chen, H. Transformation of Nitrogen and Evolution of N-Containing Species during Algae Pyrolysis. Environ. Sci. Technol. 2017, 51, 6570-6579.

(44) Fan, X.; Liu, G.-F.; Zong, Z.-M.; Zhao, X.-Y.; Cao, J.-P.; Li, B.M.; Zhao, W.; Wei, X.-Y. Mechanism for catalytic hydrodenitrogenation of isoquinoline. Fuel Process. Technol. 2013, 106, 661-665.

(45) Chiaberge, S.; Leonardis, I.; Fiorani, T.; Cesti, P.; Reale, S.; Angelis, F. D. Bio-oil from waste: a comprehensive analytical study by soft-ionization FTICR mass spectrometry. Energy Fuels 2014, 28, 2019-2026.

(46) Analytical Pyrolysis of Proteins. In Techniques and Instrumentation in Analytical Chemistry; Moldoveanu, S. C., Ed.; Elsevier, 1998; chapter 12, pp 373-397.

(47) Yamamoto, T.; Tsuji, K.; Kosuge, T.; Okamoto, T.; Shudo, K.; Takeda, K.; Iitaka, Y.; Yamaguchi, K.; Seino, Y.; Yahagi, T.; Nagao, M.; Sugimura, T. Isolation and Structure Determination of Mutagenic Substances in L-Glutamic Acid Pyrolysate. Proc. Jpn. Acad. Ser. B Phys. Biol. Sci. 1978, 54, 248-250.

(48) Qi, Y.; Hempelmann, R.; Volmer, D. A. Shedding light on the structures of lignin compounds: photo-oxidation under artificial UV light and characterization by high resolution mass spectrometry. Anal. Bioanal. Chem. 2016, 408, 8203.

(49) Qi, Y.; Fu, P.; Volmer, D. A. Analysis of natural organic matter via fourier transform ion cyclotron resonance mass spectrometry: an overview of recent non-petroleum applications. Mass Spectrom. Rev. 2020, $00,1-15$.

(50) Hertzog, J.; Carré, V.; Le Brech, Y.; Dufour, A.; Aubriet, F. Toward controlled ionization conditions for ESI-FT-ICR-MS analysis of bio-oils from lignocellulosic material. Energy Fuels 2016, 30, 57295739.

(51) Kim, S.; Kramer, R. W.; Hatcher, P. G. Graphical method for analysis of ultrahigh-resolution broadband mass spectra of natural organic matter, the van Krevelen diagram. Anal. Chem. 2003, 75, $5336-5344$.

(52) He, Z.; Guo, M.; Sleighter, R. L.; Zhang, H.; Chanel, F.; Hatcher, P. G. Characterization of defatted cottonseed meal-derived pyrolysis bio-oil by ultrahigh resolution electrospray ionization 
Fourier transform ion cyclotron resonance mass spectrometry. J. Anal. Appl. Pyrolysis 2018, 136, 96-106.

(53) Mann, B. F.; Chen, H.; Herndon, E. M.; Chu, R. K.; Tolic, N.; Portier, E. F.; Roy Chowdhury, T.; Robinson, E. W.; Callister, S. J.; Wullschleger, S. D.; Graham, D. E.; Liang, L.; Gu, B. Indexing permafrost soil organic matter degradation using high-resolution mass spectrometry. PloS One 2015, 10, No. e0130557.

(54) Koch, B. P.; Dittmar, T. From mass to structure: an aromaticity index for high-resolution mass data of natural organic matter. Rapid Commun. Mass Spectrom. 2006, 20, 926-932.

(55) Anastasakis, K.; Ross, A. B.; Jones, J. M. Pyrolysis behaviour of the main carbohydrates of brown macro-algae. Fuel 2011, 90, 598607.

(56) Wei, X.; Ma, X.; Peng, X.; Yao, Z.; Yang, F.; Dai, M. Comparative investigation between co-pyrolysis characteristics of protein and carbohydrate by TG-FTIR and Py-GC/MS. J. Anal. Appl. Pyrol. 2018, 135, 209-218.

(57) Hong, Y.; Chen, W.; Luo, X.; Pang, C.; Lester, E.; Wu, T. Microwave-enhanced pyrolysis of macroalgae and microalgae for syngas production. Bioresour. Technol. 2017, 237, 47-56.

(58) Moens, L.; Evans, R. J.; Looker, M. J.; Nimlos, M. R. A comparison of the Maillard reactivity of proline to other amino acids using pyrolysis-molecular beam mass spectrometry. Fuel 2004, 83, $1433-1443$.

(59) Shi, D.-L.; Wei, X.-Y.; Fan, X.; Zong, Z.-M.; Chen, B.; Zhao, Y.P.; Wang, Y.-G.; Cao, J.-P. Characterizations of the extracts from geting bituminous coal by spectrometries. Energy Fuels 2013, 27, 3709-3717.

(60) Ahmad, M. I.; Zhang, N.; Jobson, M. Integrated design of diesel hydrotreating processes. Chem. Eng. Res. Des. 2011, 89, 1025-1036.

(61) Hong, C.; Li, Y.; Si, Y.; Li, Z.; Xing, Y.; Chang, X.; Zheng, Z.; $\mathrm{Hu}$, J.; Zhao, X. Catalytic upgrading of penicillin fermentation residue bio-oil by metal-supported HZSM-5. Sci. Total Environ. 2021, 767, 144977. 